\title{
Systematic Literature Review of Supply Chain Relationship Approaches amongst Business-to-Business Partners
}

\author{
Faridzah Jamaluddin $(\mathbb{D}$ and Nizaroyani Saibani *(D) \\ Department of Mechanical \& Manufacturing Engineering, Faculty of Engineering and Built Environment, \\ Universiti Kebangsaan Malaysia, Bangi 43600, Malaysia; faridzahjamaluddin@gmail.com \\ * Correspondence: nizar@ukm.edu.my
}

Citation: Jamaluddin, F.; Saibani, N. Systematic Literature Review of Supply Chain Relationship Approaches amongst Business-to-Business Partners. Sustainability 2021, 13, 11935. https://doi.org/10.3390/su132111935

Academic Editor: Helena Carvalho

Received: 4 October 2021

Accepted: 27 October 2021

Published: 28 October 2021

Publisher's Note: MDPI stays neutral with regard to jurisdictional claims in published maps and institutional affiliations.

Copyright: (c) 2021 by the authors. Licensee MDPI, Basel, Switzerland. This article is an open access article distributed under the terms and conditions of the Creative Commons Attribution (CC BY) license (https:// creativecommons.org/licenses/by/ $4.0 /)$.

\begin{abstract}
Managing a business-to-business (B2B) supply chain relationship is an endless challenge. Many recent systematic literature review studies have discussed supply chain relationships from various perspectives. However, a comprehensive analysis, summarising the existing research, explicitly identified the implemented B2B supply chain relationships and found the effects of these relationships on supply chain performance remain lacking. To address the gap, this article presents a systematic literature review based on the PRISMA approach regarding the nature of the supply chain relationships between B2B partners and their effect on supply chain performance. Web of Science and Scopus were used in the compilation of studies published between 2000 and 2020. Findings indicate that the majority of B2B partners use a collaborative relationship approach and that the impacts are marked on the operational, financial, innovation, environmental, social and economic performance of their supply chain. This study seeks to contribute to the existing literature on B2B supply chain relationships by conducting a thorough and unbiased review of previous studies, drawing more general conclusions about the adopted supply chain relationships between B2B partners and providing insights for future research.
\end{abstract}

Keywords: supply chain relationship; business-to-business; collaborative relationship; trust-based; power-based; systematic literature review

\section{Introduction}

Most organisations recognise that the quality of their business partners' relationship is one of their most valuable assets in this dynamic and unpredictable world of change. According to Ryciuk and Nazarko [1], organisation functioning and development are heavily reliant on relationships with other entities. As a result, the supply chain relationship must be regarded as the foundation of supply chain management in any organisation. The quality of the business-to-business (B2B) relationship is a successful business strategy [2] that plays a crucial role in the internalisation of firms [3], as well as being a key focus of corporate marketing [4]. Managing supply chain relationships is always a challenging issue, where flexibility will be difficult to achieve if the relationship is highly restrictive, and opportunism will be present if it is too lenient [5]. It is also related to the issue of dysfunctions, which are the deviations from an enterprise's actual operation in comparison to its model operation. Marcinkowski et al. [6] in their study have identified three types of dysfunctions in B2B relationships with suppliers in the pharmaceutical industry supply chain; these are transport and storage dysfunctions (e.g., no loading time hour on the international consignment notes), communication dysfunctions (e.g., lack of information from supplier regarding delivery to the consignee) and administrative and legal dysfunctions (e.g., inadequate amount of the supplement in the delivery). These dysfunctions are the types of dysfunctions within the internal environment of the supply chain [7]. Undoubtedly, they impact operational issues, such as order handling delays, and ultimately harm business relations between the consignee and supplier [6]. In some cases, the dysfunction 
is caused by some of the most fundamental components of a highly relational exchange or a very close interpersonal bond [8]. These relationships are frequently the most vulnerable to decline or destruction [9]. Another challenging problem in supply chain relationship is supply chain disruption. It is such unpredicted and unexpected occurrences that affect the daily flow of information, financial, material or service resources both within and between supply chain organisations involved in delivering services or manufacturing goods throughout the supply chain [10]. Buyer's trust in suppliers' ability can be harmed if the supply chain is disrupted [11]. Wang et al. [12] discovered that the effect of supply chain disruption harms buyer's trust in suppliers not only in terms of their ability but also in their integrity and benevolence. Furthermore, procedural justice is the best and the most effective method for restoring buyers' trust in suppliers' integrity and benevolence [12]. Every day, the supply chain is subjected to a number of incidents that disrupt its operations, such as industrial accidents (e.g., production mishaps) [13], natural events (e.g., Thailand flood, Hurricane Katrina and Japanese tsunami) $[13,14]$, international disruptions (e.g., terrorism) [15] and the most recent unprecedented event, the COVID-19 pandemic [16]. The COVID-19 pandemic has created new challenges for supply chain managers to address. For example, during the beginning of the global outbreak in March 2020, supply chain management struggled to meet an unexpected demand for certain products when simultaneous production and travel bans were imposed [16]. Therefore, understanding the supply chain relationship between B2B partners is critical, especially during a difficult period. B2B relationships were traditionally considered to be power, opportunity or conflict [17-20]. However, over the last few decades, a telling trend has been observed in B2B markets where the marketing mindset shifted from transactional to relationship-focused [21] and towards maintaining fewer and closer relationships [22]. For instance, manufacturers decrease the number of their suppliers to search for risk sharing efficiencies and value creation [23]. According to Leonidou [24], establishing long-term relationships can assist suppliers and customers in creating higher value that is mutually beneficial. Geyskens et al. [25] claimed that inter-organisational relationships have shifted from concepts, such as conflict, power or opportunism, to variables, such as trust, long-term orientation and commitment.

Collaborative, cooperative and coordination relationships are supply chain relationships that are based on trust [26-29]. Conversely, transactional, arm's length, adversarial and competitive relationships are power-based supply chain relationships [20,30-32]. Firms prefer a collaborative relationship because they are consistently looking for new and improved strategies and processes [33-35] and long-term partnership in which people typically share information and work closely to plan [36]. Moreover, firms maintain a central goal of establishing a relationship-based synergy between individual firms' expertise and skills to collectively provide benefits to their business partners [37-39]. According to Hazen and Byrd [40], a collaborative relationship is a vital supply chain strategy that is typically required for the transfer from the production to consumption of services and goods through multiple network relationships. The characteristics of collaborative relationships include mutual benefit and trust, long-term contracts and strategies, such as cross-functional team decision making [41]. Adopting a collaborative relationship provides significant benefits to all parties, including lower costs, improved relationships and increased satisfaction and value [42]. However, collaborative relationships are risky, uncertain and complex as firms must become less opportunistic and more interdependent and give their partners a certain amount of control [33]. As stated by Min et al. [43], firms find taking action independently difficult; thus, they need to build closer cooperation with their business partners to gain and sustain their competitive advantage. A cooperative relationship evolves through repeated transactions into a long-term partnership based on trust and loyalty [1]. The alignment of a cooperative relationship is difficult; nevertheless, it allows for greater benefits than a transactional relationship [44,45]. A transactional relationship is characterised by a discrete dyadic exchange between sellers and buyers with few personal relationships. The dimensions of a transactional relationship, such as timeliness, price and availability, seem more important for customers than relationship dimensions, such as trust, commitment and 
integrity [46,47]. According to Oh [48], transactional relationships allow efficient inventory management and timely product supply, resulting in increased corporate profits. Early research tend to emphasise the significance of adversarial or arm's length relationships as the 'tried-tested' method of business operations [5]. Adversarial relationships include attributes such as short-term contracts, tough negotiation and multiple sourcing [41]. Findings from Nagle et al. [41] indicate that adversarial relationships mostly affect the sourcing phases, whereas collaborative relationships mostly affect the fulfilment and consumption phases of the procurement cycle. In coopetitive relationships, firms engage in cooperative and competitive activities at the same time [49,50]. Coopetitive relationships have received increased attention owing to an increase in market liberalisation and internalisation [49]. As stated by Raza-Ullah [50], this relationship is the most complex because of the difficulty in balancing cooperative and competitive interests. Nevertheless, coopetitive relationships are the most advantageous relationship between competitors given that such relationships offer the possibility of achieving unique benefits of cooperation and competition, provided that firms can balance and maintain relationships [50,51].

Some researchers conducted a systematic literature review (SLR) on supply chain relationships. In addition to managing perspectives on issues of supply chain coordination, Arshinder et al. [52] examined different mechanisms for managing supply chain coordination. Ralston et al. [33] examined the past and future of supply chain collaboration. Their finding reveals three distinct factors that influence collaboration, namely, relational, internal and technological factors. On the basis of a review of 174 articles, Chen et al. [53] explored the state-of-the-art and existing trends in sustainability and supply chain collaboration. Singh et al. [54] explored the necessity, evolution, types, advantages, drivers, issues and challenges and obstacles in the context of supply chain collaboration. Ho et al. [55] evaluated 43 papers on the mechanism of supply chain collaboration and its influence on performance. Wankmüller and Reiner [56] reviewed 202 academic papers on collaboration, cooperation and coordination in the field of supply chain management and relief supply chain management. Chen et al. [57] investigated the enablers of coordination across construction supply chain processes. Other researchers analysed 100 scientific papers on how the relationship quality dimensions, namely, information, operational and relational, affect the supply chain performance [58]. Recently, Aloui et al. [59] reviewed 81 journal articles on horizontal collaboration and sustainability in the freight transportation sector. Hamidin and Rofaida [60] discussed 50 academic papers on innovation drivers to an outsourcing supply chain collaborative network. Daghar et al. [61] examined 126 articles on the role of collaborative inter-organisational relationships in supply chain risks from a social capital perspective.

Despite the existing SLR on supply chain relationships [33,52-57,59-61], the present study aims to fill the aforementioned gap because it examines the current status of B2B partners' supply chain relationships in a systematic manner. Although previous researchers conducted systematic investigations into the B2B partners' relationship, they all focused solely on collaboration, coordination or cooperation. None of them concentrated on transactional, adversarial or coopetition relationships. The current study advances to the next level by examining the supply chain relationship of B2B partners, including all types of B2B partners relationships, such as collaboration, cooperation, coordination, trust-based, adversarial, competition and coopetition, as well as the effects of these relationships on supply chain performance. Data were collected through systematic reviews and metaanalyses (PRISMA) and analysed using content analysis to gain in-depth insight into how B2B partners manage their relationships and the effects of these relationships on supply chain performance. The specific research questions are as follows.

1. What type of supply chain relationship exists between B2B partners?

2. Which type of supply chain relationship is most frequently practised by B2B partners?

3. Which type of supply chain relationship is most frequently practised country by country, and if there exists any correlation between the countries studied and the type of supply chain relationship practised? 
4. How does collaborative relationships affect the supply chain performance?

5. What are the sustainability issues that B2B partners in supply chain relationships focusing on?

To answer these research questions, this study conducted a systematic review of the existing literature. A systematic review evaluates formulated questions methodically to recognise, select and critically analyse all relevant literature included in the review process. According to Higgins et al. [62], existing literature can be analysed and summarised using statistical methods. A systematic review allows researchers not only to justify the rigour of the research but also identify gaps and offer valid suggestions for future studies. This study contributes to the literature in seven ways. Firstly, it offers a general overview of B2B supply chain relationships in a more systematic way than individual studies. Understanding what has already been implemented in terms of the supply chain relationship between $\mathrm{B} 2 \mathrm{~B}$ partners is a critical step in the advancement of the concept. To the best of the authors' knowledge, no study on B2B supply chain relationship approaches has been collectively and systematically reviewed or debated. Secondly, this study explores the various types of supply chain relationship used by B2B partners. These types, identified from the content analysis, are broadly classified as trust-based, power-based and coopetitive approaches. Exploring the supply chain relationship of B2B partners is important not only theoretically but also practically. Thirdly, this study examined the most frequently practised supply chain relationships between B2B partners. As verified by content analysis, the collaborative relationship, which is a component of trust-based approaches, is the most commonly used by B2B partners. Fourthly, this study investigated the effect of collaborative relationship on supply chain performance. Knowing the positive effect of collaborative relationship on the financial, innovation, operational, economic, social and environmental performance allows business organisations to consider this type of relationship if they have not previously implemented one. Fifthly, this study looked into sustainability issues that arise in supply chain relationships, particularly between B2B partners. Understanding these issues is critical because B2B supply chain relationships play an important role in an organisation's environmental, social and economic sustainability performance. Sixthly, the content analysis revealed several topic areas, which were emphasised as suggestions for future research in the area of supply chain relationships. Understanding previous research in the field is beneficial to researchers and practitioners. Finally, the procedure for conducting SLR was detailed, with step-by-step instructions. This approach not only demonstrates the exact stage and phases of the SLR process for the current work but also serves as a guide for future researchers using the same method.

The remainder of this paper is organised as follows. Section 2 outlines the method, and Section 3 describes the findings of the descriptive analysis. Section 4 presents the findings of the content analysis. Section 5 provides discussion and future research directions. Finally, Section 6 is the conclusion.

\section{Methodology}

This section explains the approach utilised to obtain and analyse the available literature on supply chain relationships amongst B2B partners. The preferred reporting items for the PRISMA method were used for the retrieval of all the available existing studies, to review the steps in the process (identification, screening and eligibility) and for data abstraction and data analysis, as PRISMA caters to two resource databases, namely, Web of Science (WoS) and Scopus.

\subsection{PRISMA Method}

Throughout the systematic review, PRISMA was applied in the area of supply chain management to guide the data collection process [63]. The advantages of PRISMA include the ability to (i) define clear research questions; (ii) classify the inclusion and exclusion criteria; and (iii) assess large databases of literature within a specific time frame [64]. 
Therefore, PRISMA can thoroughly search for literature or papers related to supply chain relationships amongst $\mathrm{B} 2 \mathrm{~B}$ partners.

\subsection{Resources}

In this review, the literature was compiled primarily from two databases, namely, WoS and Scopus, as they offer comprehensive searching tools. WoS is an online citation indexing database originally produced by the Institute for Scientific Information but currently maintained by Clarivate Analytics and includes more than 30,000 journals [65]. It is one of the most highly regarded scientific citation search engines in the world and is often used as an academic library research tool as it offers comprehensive citation data [66]. Meanwhile, Scopus comprises more than 75 million items and 24,600 peer-reviewed journals from over 5000 publishers. With smart tools to track, analyse and visualise research, Scopus is the largest peer-reviewed abstract and citation literature database, which makes research workflow effective and efficient [67].

\subsection{Eligibility and Exclusion Criteria}

As depicted in Table 1, the eligibility criteria for inclusion in this study were (i) only journal papers, as they contain more mature and complete reports of their research [68]; (ii) only publications in the English language, to ease the search and analysis of the literature; and (iii) only articles that focus on supply chain relationships and B2B partners.

Table 1. Inclusion and exclusion criteria.

\begin{tabular}{ccc}
\hline Criterion & Eligibility & Exclusion \\
\hline Literature type & Journal articles including case studies & Review articles, conference reports, and chapters from books \\
Language & English & Non-English \\
Discipline & Supply chain relationship & Other than supply chain relationship \\
Focus of study & Supply chain relationship approaches, B2B & Other than supply chain relationship approaches, B2B \\
\hline
\end{tabular}

\subsection{Systematic Review Process}

The integrative systematic review of both databases was performed in August 2020 and comprised of four stages. According to Jackson et al. [69], an integrative systematic review compiles papers using quantitative, qualitative and mixed methods, thereby creating a rich overview of papers with multiple research approaches. The first stage involved identifying keywords to be used in the search process. Several keywords related to supply chain relationship approaches and B2B were shortlisted. Retrieving literature from WoS and Scopus using the complete features of these databases was easy. Table 2 presents the search strings utilised in both databases.

Table 2. Search strings used in the SLR.

\begin{tabular}{|c|c|c|}
\hline Journal Database & Search String & Frequency of Hits \\
\hline WoS & $\begin{array}{l}\text { TOPIC: ("adversarial relationship*" OR “arm's-length } \\
\text { relationship*" OR “transactional relationship*" OR “competiti* } \\
\text { relationship*" OR “collaborati* relationship*" OR “cooperati* } \\
\text { relationship*" OR “coordinati* relationship*" OR “coopetiti } \\
\text { relationship") AND TOPIC: (“business to business" OR “B2B" OR } \\
\text { "supply chain relationship*" OR “supply chain*") }\end{array}$ & 472 \\
\hline Scopus & 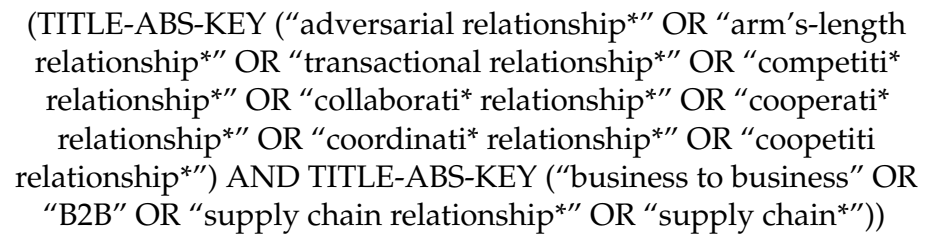 & 357 \\
\hline
\end{tabular}

The search strings matched a total of 829 papers from WoS and Scopus. A total of 248 duplicate papers were eliminated in the identification stage. Then, 252 papers were 
excluded during screening, and 222 papers were further removed in the eligibility stage. Upon completion of this tremendously demanding, time-consuming and rigid systematic review [70], only 67 primary studies that focused on the research topic were retained. As the development of a review protocol is vital for rigorous systematic review [71], Figure 1 depict the PRISMA flow diagram utilised in this study

\subsection{Data Abstraction and Analysis}

The shortlisted 67 papers were analysed. Descriptive analysis was used to summarise the selected papers, and content analysis was utilised to address the research questions. Content analysis codes data from each primary study under broad themes before the occurrences of these themes are analysed [72]. The theme of the present study was supply chain relationship approaches. Abstracts were initially analysed before the full paper was evaluated. Raw data were extracted to address the research questions. Then, these data were manually coded into different themes according to supply chain relationship approaches.

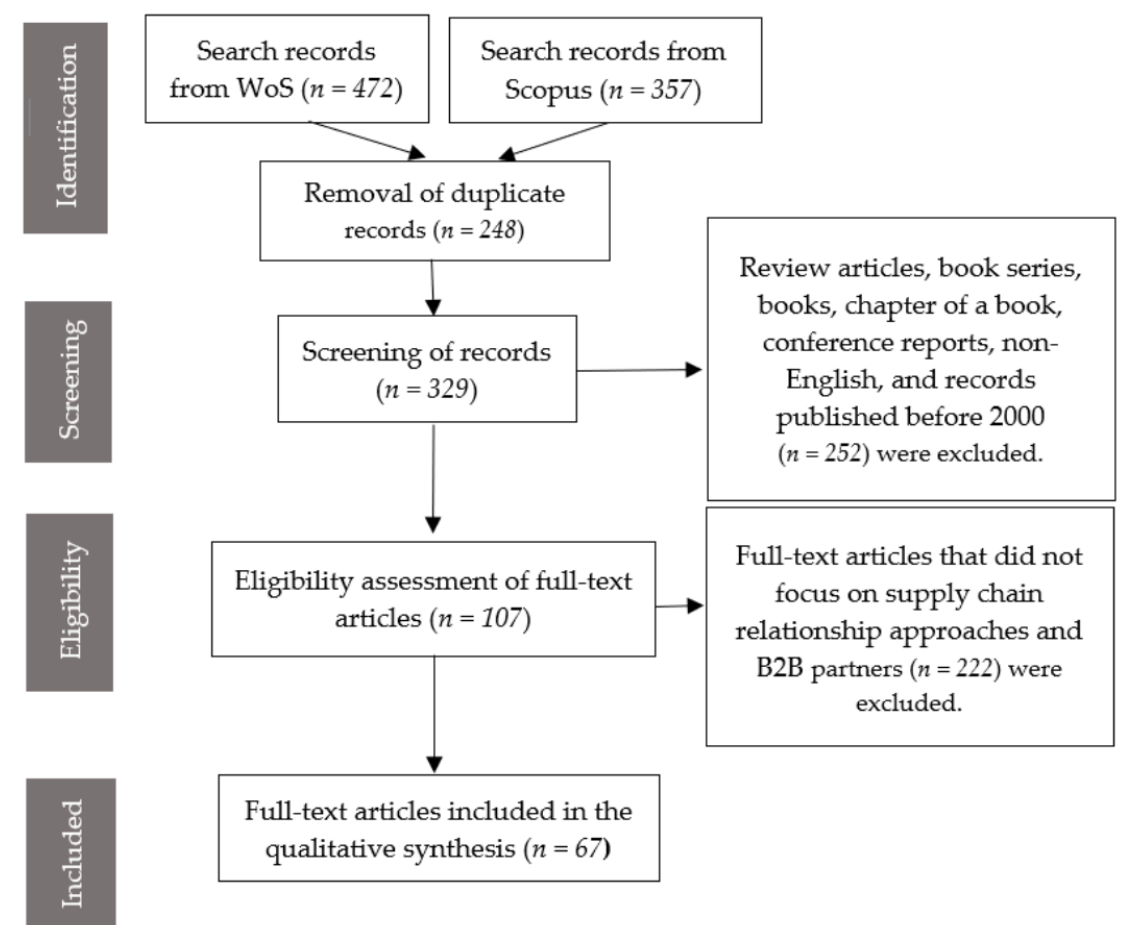

Figure 1. The PRISMA flow diagram of the study (Source: [73]).

\section{Descriptive Analysis}

An overview of papers about supply chain relationships amongst B2B partners is provided in this section. Except for 2017, a negatively skewed pattern of distribution is observed amongst the 67 papers analysed and distributed between 2000 and 2020, indicating the increasing importance of the subject of supply chain relationships between B2B partners, as shown in Figure 2. Figure 2 shows that 5 out of the 67 papers included in the study were published between 2000 and 2005, 13 papers between 2006 and 2010, 23 papers between 2011 and 2015 and 26 papers between 2016 and 2020. This finding indicates an upward trend in the publication of these papers, with more than half having been published in the last 10 years. 


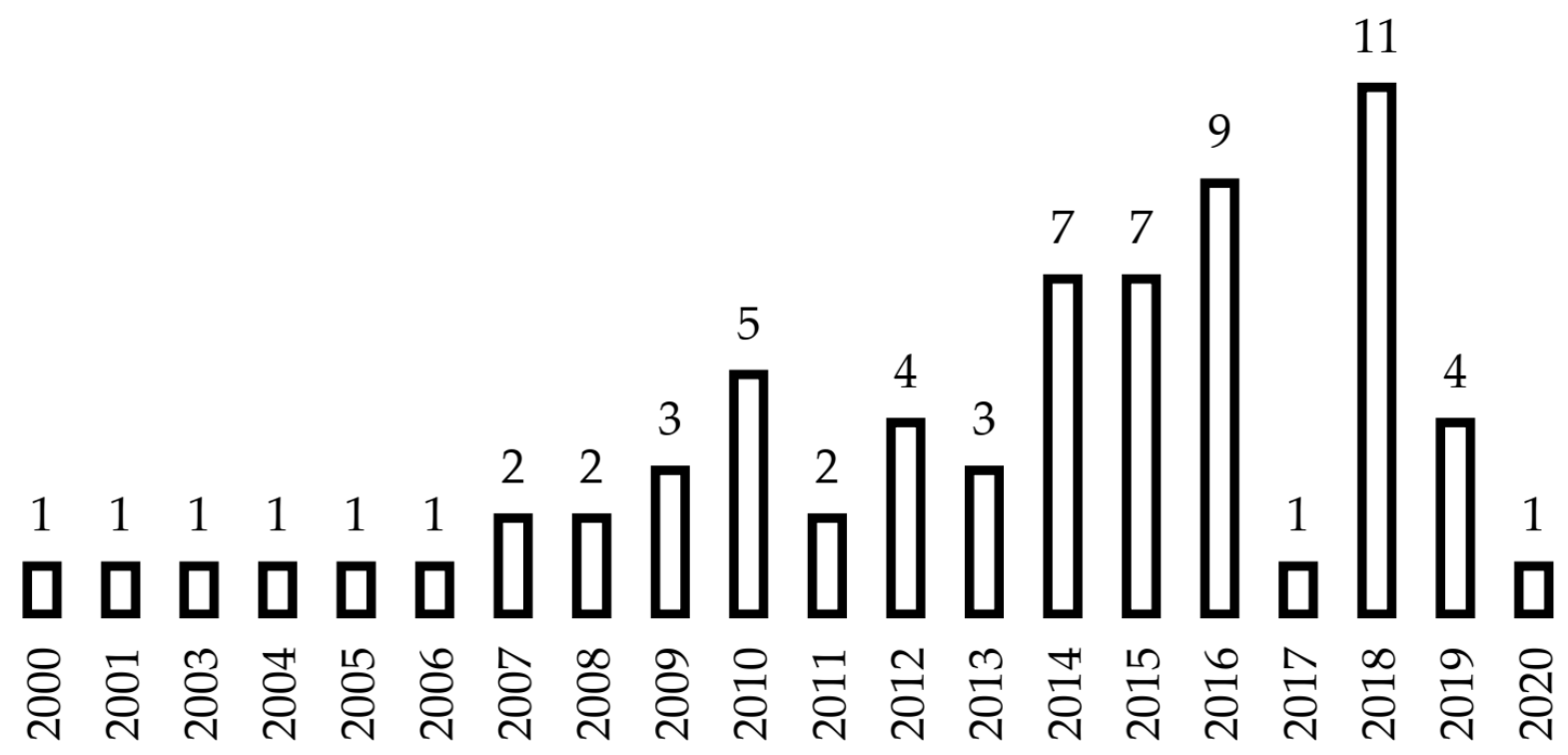

Figure 2. Publication of papers over time.

The distribution of 67 papers across 54 journals demonstrates that a wide range of journals addresses the topic of supply chain relationship approaches amongst B2B partners (Figure 3). Particularly, only one journal published four papers on the subject, one journal published three papers, eight journals published two papers and the remaining 44 journals published one paper each.

One journal had four papers in the top six journals with the highest impact factors, one journal had three papers, three journals appeared with two papers and the remaining one journal had one paper, as presented in Table 3. The Journal of Supply Chain Management is the top journal for scholars of supply chain management across disciplines, attracting high-quality, high-impact behavioural research with an emphasis on theory and empirical methodology. This journal has an 8.647 impact factor in 2019 and is published by Wiley Online Library. As a result of these factors, the Journal of Supply Chain Management is widely cited in the field of supply chain management, as well as related disciplines, such as transaction cost economics, marketing channels and strategy, operation management, strategic management and social network analysis, which explains the disparity in comparison to other journals, particularly Sustainability, as reported in Table 3.

The most cited papers from the 67 papers cover a wide range of topics, including the collaborative relationships from suppliers and buyers' perspectives; the effects of collaborative relationships on firm operation and innovation; UK contractors' perceptions of collaborative relationships, characteristics, requirements, benefits and barriers to various collaborative relationships; innovation-cooperation relationship of small- and mediumsized enterprises (SMEs); and a collaborative relationship as a mediator variable (Table 4). As shown in Figure 4, the majority of the studies, 37 out of 67, used questionnaires for data collection. 


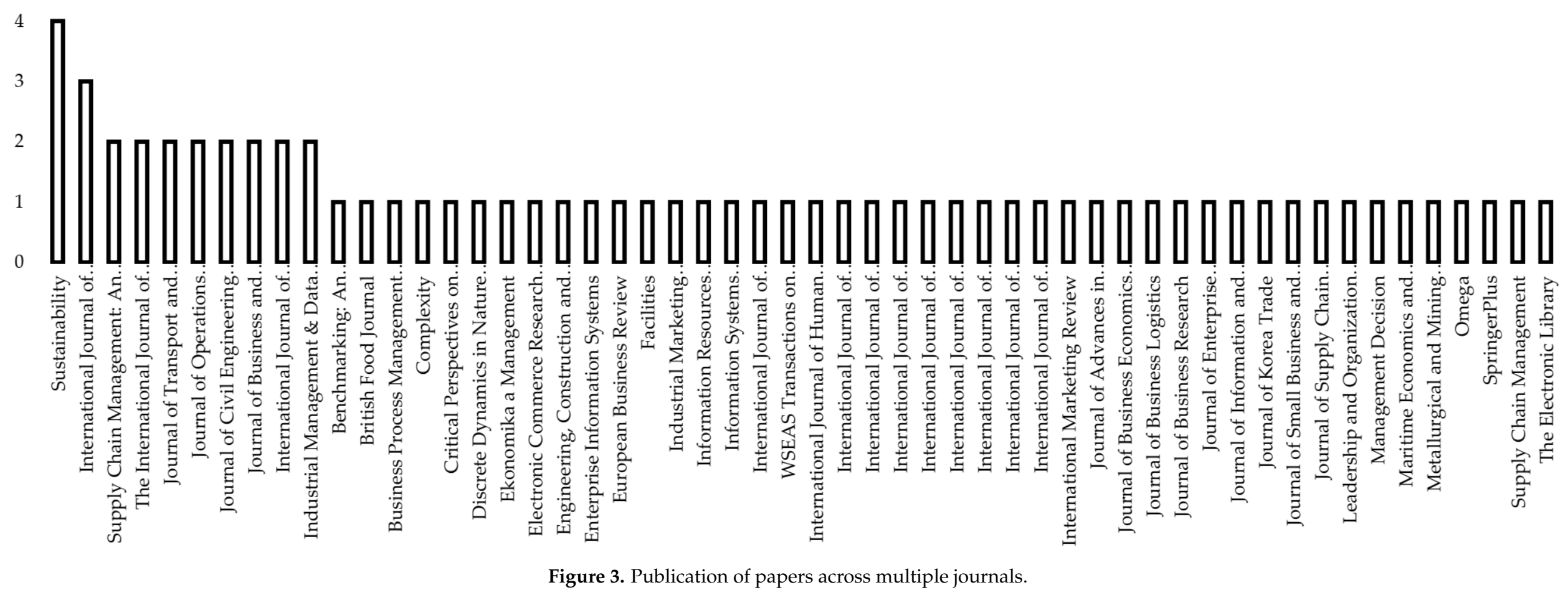


Table 3. Journals with the highest impact factors and the number of articles.

\begin{tabular}{ccc}
\hline Journal & Impact Factor & No. of Article \\
\hline Journal of Supply Chain Management & 8.647 & 1 \\
Journal of Operations Management & 6.970 & 2 \\
International Journal of Production Economics & 5.134 & 3 \\
Industrial Management E Data Systems & 4.791 & 2 \\
International Journal of Production Research & 4.577 & 2 \\
Sustainability & 3.251 & 4 \\
\hline
\end{tabular}

Table 4. Most cited articles.

\begin{tabular}{|c|c|c|c|c|}
\hline Author & Article Title & Journal & $\begin{array}{c}\text { No. } \\
\text { Citations }\end{array}$ & Subject \\
\hline [45] & $\begin{array}{l}\text { Examining supply chain } \\
\text { relationships: Do buyer and supplier } \\
\text { perspectives on collaborative } \\
\text { relationships differ? }\end{array}$ & $\begin{array}{l}\text { Journal of Operations } \\
\text { Management }\end{array}$ & 1178 & $\begin{array}{l}\text { Examine the collaborative } \\
\text { relationships from both suppliers and } \\
\text { buyers' perceptions. }\end{array}$ \\
\hline$[74]$ & $\begin{array}{l}\text { Supply chain collaboration: } \\
\text { Capabilities for } \\
\text { continuous innovation }\end{array}$ & $\begin{array}{c}\text { Supply Chain } \\
\text { Management: An } \\
\text { International Journal }\end{array}$ & 676 & $\begin{array}{l}\text { Investigate the impact of collaborative } \\
\text { relationships on the operation of firms } \\
\text { and continuous innovation }\end{array}$ \\
\hline [75] & $\begin{array}{l}\text { Building supply chain collaboration: } \\
\text { a typology of } \\
\text { collaborative approaches. }\end{array}$ & $\begin{array}{l}\text { The International Journal } \\
\text { of Logistics Management }\end{array}$ & 299 & $\begin{array}{l}\text { Examine the characteristics, } \\
\text { requirements, benefits, and barriers to } \\
\text { various collaborative relationships }\end{array}$ \\
\hline [76] & $\begin{array}{l}\text { Collaborative relationships in } \\
\text { construction: The UK } \\
\text { contractors' perception. }\end{array}$ & $\begin{array}{l}\text { Engineering, } \\
\text { Construction and } \\
\text { Architectural } \\
\text { Management }\end{array}$ & 250 & $\begin{array}{c}\text { Describe UK contractors' perceptions } \\
\text { of collaborative } \\
\text { relationships in construction }\end{array}$ \\
\hline [77] & $\begin{array}{l}\text { The nature of SME co-operation and } \\
\text { innovation: A multi-scalar and } \\
\text { multi-dimensional analysis. }\end{array}$ & $\begin{array}{l}\text { Construction and } \\
\text { Architectural } \\
\text { Management }\end{array}$ & 228 & $\begin{array}{l}\text { Explore the SME } \\
\text { innovation-cooperation relationship }\end{array}$ \\
\hline [78] & $\begin{array}{l}\text { Joint supply chain risk management: } \\
\text { An agency and } \\
\text { collaboration perspective. }\end{array}$ & $\begin{array}{l}\text { International Journal of } \\
\text { Production Economics }\end{array}$ & 206 & $\begin{array}{l}\text { Examine the mediate effect of a } \\
\text { collaborative relationship between } \\
\text { risk and financial performance }\end{array}$ \\
\hline
\end{tabular}

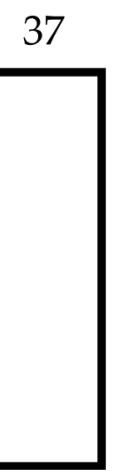

Questionnaire

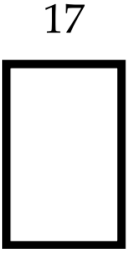

Interviews

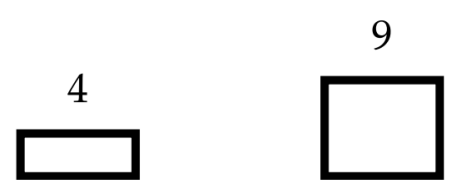

Mixed methods Secondary data (interview \& survey)

Figure 4. Published papers according to the adopted methodology.

\section{Content Analysis}

The 67 papers eligible for this study were evaluated in terms of (i) approaches to supply chain relationships amongst B2B partners; (ii) distribution of B2B supply chain relationship approaches across countries; (iii) effect of collaborative relationship on supply chain performance; and (iv) sustainability issues arise in B2B supply chain relationships. 


\subsection{B2B Supply Chain Relationship}

Analyses of these papers revealed that the supply chain relationship approaches amongst B2B partners can be classified into three broad categories, namely, (i) trust-based; (ii) power-based; and (iii) coopetition. A trust-based approach includes collaborative, cooperative and coordination relationships. In contrast, a power-based approach includes adversarial, transactional and competitive relationships. The coopetition approach combines cooperative and competitive approaches. Past research has looked into (i) trust-based approach; (ii) power-based approach; (iii) coopetition approach; (iv) trust- and powerbased approaches; and (v) trust-based and coopetition approaches, as presented in Table 5. About $73.13 \%$ of the reviewed papers focused on collaborative relationships, $19.40 \%$ on cooperative relationships, $7.46 \%$ on transactional relationships, $2.99 \%$ on competitive and coopetitive relationships and $1.49 \%$ on coordination and adversarial relationships.

Table 5. Supply chain relationship approaches between B2B partners and types of industry.

\begin{tabular}{|c|c|c|c|c|c|c|c|c|c|c|c|c|c|c|c|c|}
\hline \multirow[t]{2}{*}{ Author } & \multicolumn{7}{|c|}{ Supply Chain Relationship } & \multicolumn{9}{|c|}{ Industry } \\
\hline & 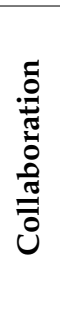 & 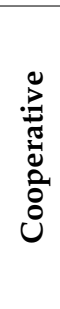 & 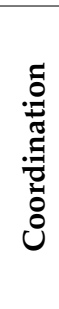 & 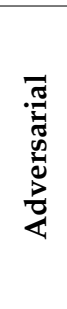 & 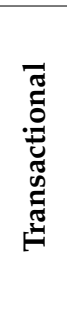 & 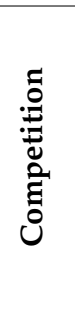 & 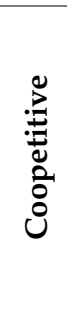 & 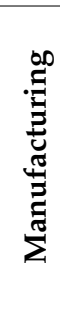 & 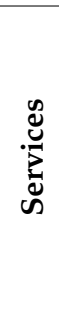 & : & 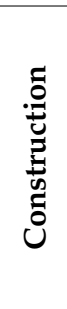 & $\begin{array}{l}\stackrel{0}{0} \\
\stackrel{0}{60} \\
0 \\
0 \\
0\end{array}$ & $\Xi$ & 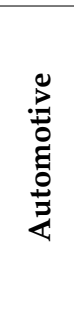 & 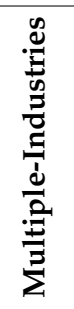 & 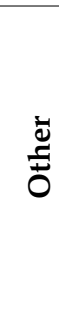 \\
\hline [79] & $x$ & & & & & & & • & & & & & & & & \\
\hline [75] & $x$ & & & & & & & • & & & & & & & & \\
\hline [80] & $x$ & & & & & & & • & & & & & & & & \\
\hline [81] & $x$ & & & & & & & • & & & & & & & & \\
\hline [89] & $x$ & & & & & & & • & & & & & & & & \\
\hline [82] & $x$ & & & & & & & • & & & & & & & & \\
\hline [83] & $x$ & & & & & & & • & & & & & & & & \\
\hline [84] & $x$ & & & & & & & $\bullet$ & & & & & & & & \\
\hline [85] & $x$ & & & & & & & • & & & & & & & & \\
\hline [78] & $x$ & & & & & & & • & & & & & & & & \\
\hline [28] & $x$ & & & & & & & • & & & & & & & & \\
\hline [87] & $x$ & & & & & & & • & & & & & & & & \\
\hline [88] & $x$ & & & & & & & • & & & & & & & & \\
\hline [90] & $x$ & & & & & & & • & & & & & & & & \\
\hline [86] & $x$ & & & & & & & • & & & & & & & & \\
\hline [91] & & $x$ & & & & & & • & & & & & & & & \\
\hline [92] & & $x$ & & & & & & • & & & & & & & & \\
\hline [93] & & $x$ & & & & & & - & & & & & & & & \\
\hline [94] & & $x$ & & & & & & • & & & & & & & & \\
\hline [96] & $x$ & & & & & & & & $\bullet$ & & & & & & & \\
\hline [95] & $x$ & & & & & & & & $\bullet$ & & & & & & & \\
\hline [97] & $x$ & & & & & & & & $\bullet$ & & & & & & & \\
\hline [99] & $x$ & & & & & & & & $\bullet$ & & & & & & & \\
\hline [98] & $x$ & & & & & & & & $\bullet$ & & & & & & & \\
\hline [100] & $\mathrm{x}$ & & & & & & & & $\bullet$ & & & & & & & \\
\hline [18] & $x$ & & & & & & & & & • & & & & & & \\
\hline [101] & $x$ & & & & & & & & & • & & & & & & \\
\hline [19] & $x$ & & & & & & & & & • & & & & & & \\
\hline [102] & $x$ & & & & & & & & & • & & & & & & \\
\hline [27] & & & $x$ & & & & & & & • & & & & & & \\
\hline [76] & $x$ & & & & & & & & & & $\bullet$ & & & & & \\
\hline [103] & $x$ & & & & & & & & & & • & & & & & \\
\hline [104] & & $x$ & & & & & & & & & • & & & & & \\
\hline
\end{tabular}


Table 5. Cont.

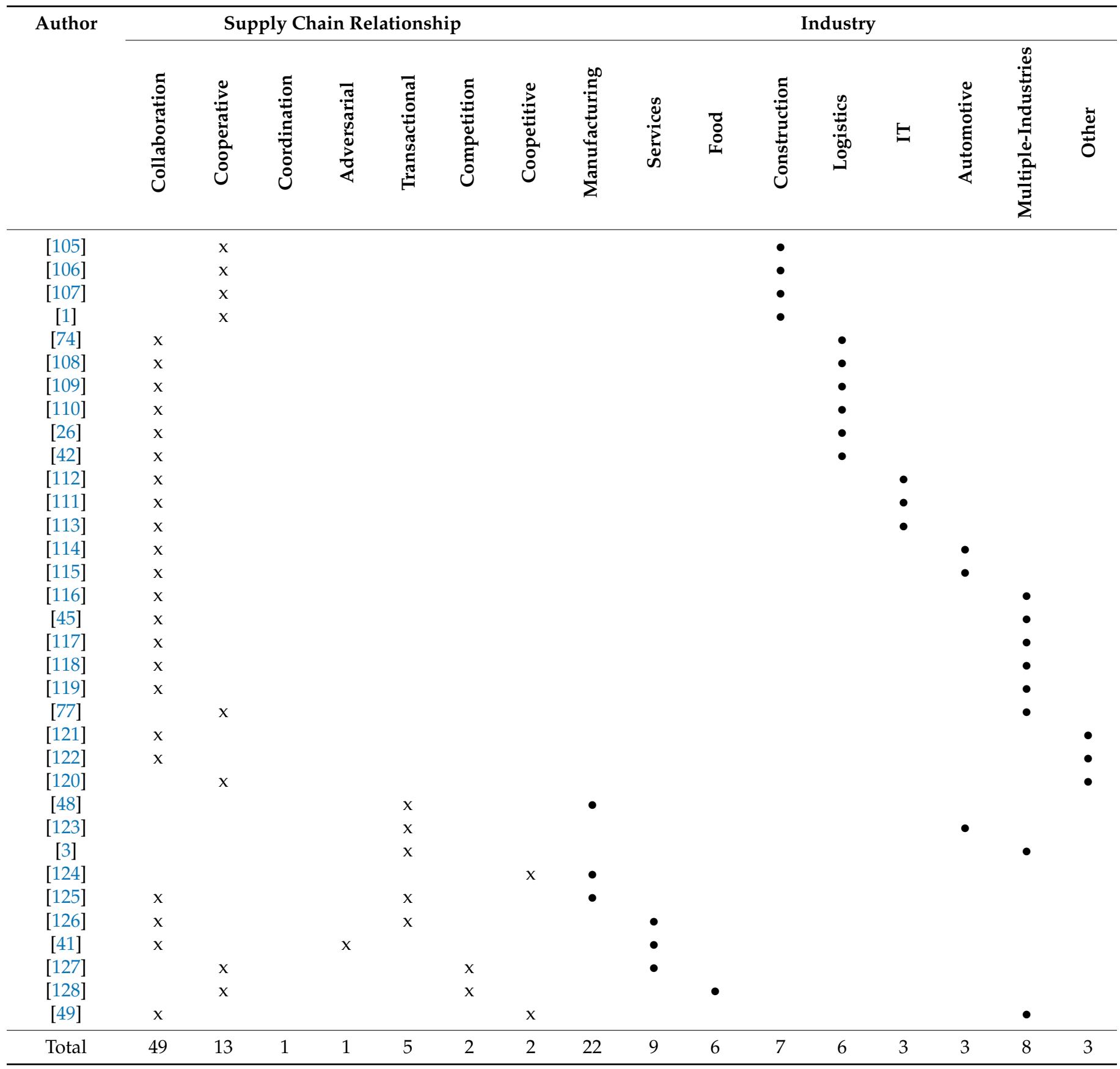

Note: " $\mathrm{x}$ " indicates the supply chain relationship approach used in the selected papers; "•" indicates the type of industry in the selected papers.

\subsubsection{Trust-Based Approach}

The trust-based approach is used by B2B partners in a variety of industries, including manufacturing, services, food, construction, logistics and transportation, information technology, automotive, multiple industries and others, as depicted in Table 5. In manufacturing industries, for instance, Humphreys et al. [79] assessed the relative importance of Hong Kong large companies' requirements when developing collaborative relationships with strategic suppliers. Using a qualitative approach, Whipple and Russell [75] investigated various collaborative relationships between manufacturer and retailer. Other studies investigated the collaborative relationship between Taiwanese electronics companies as well as international buyers [80]; customers and manufacturers are from a diverse range of manufacturing industries, including chemical and pharmaceuticals, 
food and related products, electronic products and industrial machinery [81]; industrial and supply partners [82]; fashionable consumer electronics products brander-retailer [83]; buyers-suppliers of manufacturing firms [84]; Spanish manufacturing firm's buyers and suppliers as well as subsidiaries of multinational corporations operating in Spain [85]; customers and suppliers of manufacturing [78]; first- and second-tier manufacturer suppliers in South Africa automotive supply chains [28]; and buyers and suppliers [86-88]. Jones et al. [89] studied collaborative relationships in small- and medium-sized businesses. Gandhi et al. [90] analysed the collaborative relationships between manufacturers and distributors in the context of Indian small and medium enterprises (SMEs). Chaston and Mangles [91] investigated the learning styles of small UK manufacturing firms that have a cooperative relationship with other members of their supply chain market. Si and Ma [92] assessed the cooperative relationship between the manufacturer, dealer and recycler in the remanufacturing system. Ming and Shuyu [93] looked into the cooperative relationship between the manufacturer and the retailer, whereas Yeh [94] examined the cooperative relationship between the manufacturers and suppliers.

In the service industries, Yazici [95] evaluated buyer perceptions of the buyer-supplier collaborative relationship in the US service organisation. Other studies investigated the collaborative relationship between buyers and suppliers of facilities services [96], buyer and suppliers of facilities management services [97], different players in the South African conveyancing system [98] and collaborative activities between business service providers with other firms [99]. Pongsathornwiwat et al. [100] investigated the hospitality managers collaborative relationships with local suppliers and competitors.

In the food industries, Duffy and Fearne [18] investigated the nature of buyer-supplier relationships in the UK food industry and discovered that they are becoming increasingly interdependent. Kottila and Rönni [101] confirmed the presence of collaborative trustbased relationships throughout the Finnish organic foods chain, from the farmers to the multiple retailers, for yoghurt and muesli chains. Kähkönen [19] studied the collaborative relationship between buyers and suppliers in the Finnish food industry networks. LeónBravo et al. [102] investigated the implementation of collaborative relationships at various stages of the food supply chain. Lemma et al. [27] investigated the coordination relationship between milk and dairy industry suppliers, retailers and processors.

In construction industries, according to the findings of Akintoye and Main [76], UK contractors are eager to collaborate with another contractor, subcontractor, client, consultant or supplier, and they engage in collaborative relationships for construction developments. Ho et al. [103] examined the use of business intelligence tools to assist SMEs in improving collaborative supplier relationships. Yin et al. [104] discovered that the lean subcontracting procurement process fosters cooperative relationships between participating contracts. Zhu et al. [105] investigated contractors cooperation in the green supply chain of mega projects. Shi et al. [106] examined the cooperative relationship of multiple suppliers in large construction projects. Song et al. [107] assessed the cooperative relationship between construction project owners and contractors. Ryciuk and Nazarko [1] developed a model of trust-based cooperative relationships between supply chain partners.

In logistic industries, Soosay et al. [74] investigated and validated the collaborative relationships of logistics organisations with their customers and suppliers. Chen et al. [108] investigated the enablers of coordination across construction supply chain processes. Other studies explore the collaborative relationship between container ports and related maritime logistics companies [109], exporters and logistic service providers [110] and supply chain $[26,42]$.

In IT industries, Cha and Kim [111] investigated the collaborative relationship with suppliers in a Korean IT outsourcing firm. Other researchers examined the buyer-supplier collaborative relationship in IT outsourcing [112] and Indian brand-reseller business collaborative relationship [113].

In automotive industries, Lockström et al. [114] discovered that the foundation for collaborative relationships with domestic suppliers in the Chinese automotive industry 
has yet to be established. Lettice et al. [115] investigated the collaborative buyer-supplier relationships in the automotive industry in the UK, Europe, Japan and the US.

In multiple-industries, based on the findings of Wu and Chuang [116], good collaborative relationships between trading partners are critical during the assimilation stage of the innovation diffusion of electronic supply chain management. Nyaga et al. [45] evaluated collaborative relationships from buyer and supplier perspectives in a variety of industries, including wholesale, retail, transportation and manufacturing. Other researchers evaluated the customers and suppliers relationship in manufacturing and construction industries [117] and supply chain collaboration in manufacturing and services industries [118]. The relationship between buyers and suppliers of various industries, including food and pharmaceuticals, transportation and distribution, manufacturing and others, was studied by [119]. Tomlinson and Fai [77] looked into the cooperative relationship between manufacturers and buyers and manufacturers and suppliers in the small- and mediumsized manufacturers in five industrial sectors in the UK: ceramics, textiles, aero-space, information technology and software and healthcare.

In other industries, the high levels of engagement, such as open communication and participatory decision making between focal and recipient firms, are linked to the timely adoption of technological innovations in the healthcare industry [120]. Other studies investigated the collaborative relationship between suppliers of photovoltaic systems [121] and UK farmers [122].

\subsubsection{Power-Based Approach}

The power-based approach is used between B2B partners in a range of industries, such as the manufacturing industry, automotive industry and multiple-industries. In the manufacturing industry, Oh [48] looked into the transactional relationship between manufacturers, customers, and suppliers. Wood et al. [123] demonstrated how collaborative relationships are changing to transactional relationships between automotive companies and suppliers in Brazil. Beier et al. [3] examined the transactional relationship between Swiss small and medium-sized enterprises and publicly traded domestic companies in construction, services, retail and manufacturing industries.

\subsubsection{Coopetition Approach}

Coopetition approach is used among B2B partners in the manufacturing industry. For example, Ding et al. [124] investigated the coopetition relationship between manufacturers and collectors in waste mobile phone collection.

\subsubsection{Trust- and Power-Based Approaches}

B2B partners use a combination of trust-based and power-based relationship approaches in several industries, including manufacturing, service and food industries. For instance, in manufacturing, He et al. [125] investigated the collaborative and transactional relationships that exist between computer manufacturing suppliers and distributors.

In the in service industry, the effects of adversarial and collaborative relationships on the electronically supported transaction phases of the procurement lifecycle were investigated by [41]. Their findings reveal that adversarial relationships have the greatest impact on the procurement cycle's sourcing phases, whereas collaborative relationships have the most influence on the fulfilment and consumption phases. Gnanlet and Choi [126] explored hospitals' purchasing strategy, which included both collaborative and transactional relationships with medical supply distributors. Zhao et al. [127] investigated the cooperative and competitive relationships that exist between Chinese big data-based e-commerce financial institutions and commercial banks.

In the food industry, Ayakwah et al. [128] investigated the cooperative and competitive relationships between farmers and processors, processors and processors, and processors and distributors in two selected food-processing clusters in Ghana. 


\subsubsection{Trust-Based and Coopetition Approaches}

Galdeano-Gómez et al. [49] studied the collaborative and coopetition relationships of the farming-marketing sector with their retailers and wholesalers. Collaboration is an important factor in improving exporting activity for farming-marketing firms with little bargaining power in the fresh produce supply chain. However, to reduce the traditionally negative effect of competition between Spanish companies in the marketing of vegetables, a greater balance in coopetitive relationships is needed.

\subsection{Distribution of Supply Chain Relationship Approaches across Countries}

Except for Switzerland, Brazil and Poland, researchers from all of the investigated countries have examined trust-based approaches, namely, collaborative, cooperative and coordination relationships in their B2B relationships, as depicted in Figure 5. Most papers on supply chain relationship approaches amongst B2B partners have been published in China, the US and the UK. Chinese researchers are particularly interested in trust-based approaches, trust- and power-based approaches and coopetition approaches, whereas researchers from the US and the UK have concentrated solely on trust-based approaches and trust- and power-based approaches.

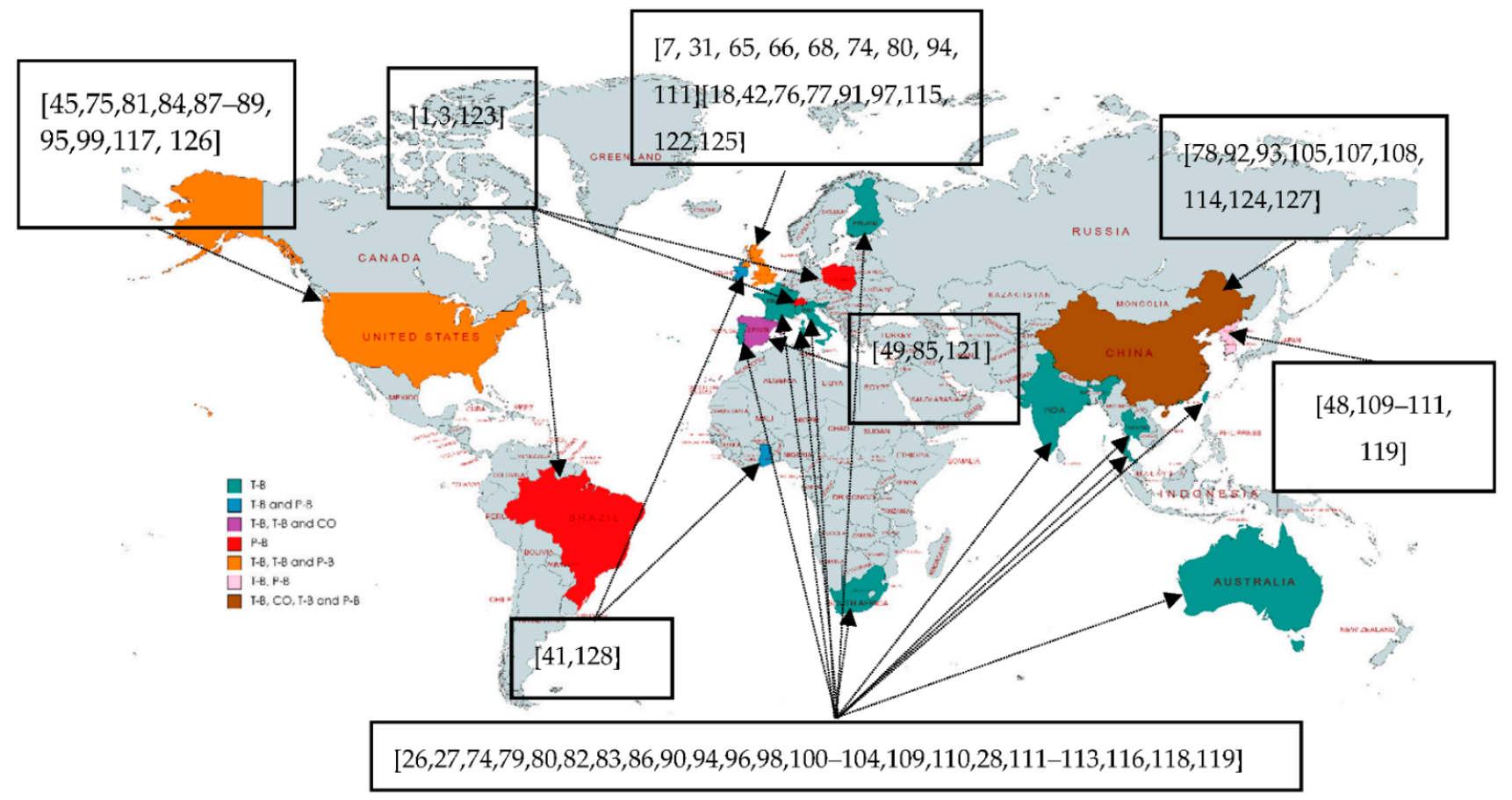

Figure 5. Distribution and types of supply chain relationship approaches worldwide.

\subsection{Collaborative Relationship and Supply Chain Performance}

An analysis of 22 papers revealed that collaborative relationships affect six aspects of supply chain performance, namely, financial, innovation, operational, environmental, social and economic, as presented in Table 6. 
Table 6. Impact of a collaborative relationship on supply chain performance.

\begin{tabular}{|c|c|c|c|c|c|c|}
\hline \multirow{2}{*}{ Author } & \multicolumn{6}{|c|}{ Supply Chain Performance } \\
\hline & 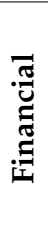 & 莞 & 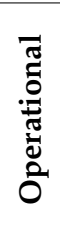 & 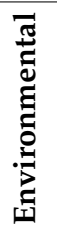 & 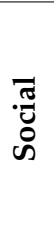 & 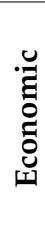 \\
\hline [18] & $\mathrm{x}$ & & & & & $x$ \\
\hline [75] & $x$ & & $x$ & & & $\mathrm{x}$ \\
\hline [74] & & $x$ & $x$ & & & $\mathrm{x}$ \\
\hline [119] & $x$ & & $x$ & & & $x$ \\
\hline [80] & & $x$ & $x$ & & & $\mathrm{x}$ \\
\hline [81] & & & $x$ & & & \\
\hline [121] & $x$ & $x$ & $x$ & & & \\
\hline [117] & $\mathrm{x}$ & & $x$ & & & \\
\hline [95] & $x$ & & & & & \\
\hline [89] & $x$ & & $x$ & & & \\
\hline [82] & & & $x$ & & & \\
\hline [83] & $\mathrm{x}$ & & $\mathrm{x}$ & $\mathrm{x}$ & $\mathrm{x}$ & $\mathrm{x}$ \\
\hline [85] & & $x$ & $x$ & & & \\
\hline [78] & $x$ & & & & & \\
\hline [110] & & & $x$ & & $\mathrm{x}$ & $x$ \\
\hline [98] & & & $x$ & & & \\
\hline [102] & & & & $\mathrm{x}$ & $x$ & \\
\hline [87] & & & $x$ & & & \\
\hline [112] & $x$ & & $x$ & & $x$ & $x$ \\
\hline [86] & & $x$ & $x$ & & & \\
\hline [100] & & & $x$ & & & \\
\hline [122] & & & & $x$ & $x$ & \\
\hline
\end{tabular}

\subsubsection{Financial, Operational, Environmental, Social and Economic Performance}

Sheu [83] surveyed retailers in FCEP brander-retailer distribution channels to examine the effect of retailers and the contracted branders' collaborative relationship towards green supply chain performance. The green supply chain performance was measured in terms of financial, operational, environmental, social and economic performance. The results for structural equation modelling indicated that the collaboration between retailers and the contracted branders increased sales and profits; increased operational and investment costs saved; improved inventory levels; met datelines for delivery, used-product collection requirements and the government's environmental regulations; provided effective used-product collection; assisted each other in obtaining ISO14000 certificates; achieved electronic waste management objectives; improved green brand images; and increased customer awareness of environmental issues.

\subsubsection{Financial, Operational, Social and Economic Performance}

Martins et al. [112] investigated the effect of buyer-supplier collaborative relationships on buyer performance in IT outsourcing businesses in Portugal. Their findings indicated that a collaborative relationship increased forecast precision, decreased workforce, improved delivery timeliness, increased profitability, improved processing precision and reduced costs and order cycle times.

\subsubsection{Financial, Operational and Economic Performance}

Whipple and Russell [75] conducted exploratory interviews with 21 managers from 10 companies in the consumer goods, food and hard-line industries. According to the results, the collaborative relationship eliminated errors, reduced costs, increased sales, reduced the required safety stock levels, increased the forecast accuracy, improved the 
in-stock levels, improved the fill rate and improved promotional servicing. Ryu et al. [119] surveyed 141 South Korean buyer-supplier practitioners via an online questionnaire, and results from the structural equation modelling indicated that the collaborative relationships reduced the product delivery cycle time, improved productivity, decreased operating and labour costs, increased revenue, increased return on assets and increased the relative market share.

\subsubsection{Financial, Innovation and Operational Performances}

Verdecho et al. [121] examined the effect of collaborative inter-enterprise relationship on financial, innovation and operational performances in a case study of a renewable energy company in Spain. They discovered that the collaborative relationship increased turnover, profitability and the level of anticipatory response to industry changes and decreased the total cycle time.

\subsubsection{Operational, Social and Economic Performances}

Park and Jeong [110] conducted a survey of 146 Korean exporters to investigate the effect of collaborative relationship between exporters and logistics service providers. The results of partial least square structural equation modelling indicated that collaborative relationships increased exporter satisfaction and exporters' cost savings, met on-time delivery services and achieved overall delivery service stability.

\subsubsection{Innovation, Operational and Economic Performance}

Soosay et al. [74] conducted a semi-structured interview with 23 logistics managers in 10 case studies. They found that collaborative relationships successfully enhanced the incremental and radical innovations, enhanced processes, improved quality, resulted in more efficient operations, reduced costs, improved customer services and relationships, increased productivity, improved strategic focus and reduced cycle time. A survey of 246 Taiwanese electronics firms by Jean and Sinkovics [80] evaluated the effect of collaborative relationships between Taiwanese electronics firms and international buyers. The results from the structural equation modelling indicated that collaborative relationship improved the performance outcomes in terms of an increase in the creation of new products, product enhancements, better product quality, reduced production cost, increased cost efficiencies and improved current processes.

\subsubsection{Financial and Economic Performance}

Duffy and Fearne [18] examined the financial and economic effects of collaborative and cooperative relationships between 337 UK retailers and fresh produce suppliers. Their finding revealed that the suppliers who engage in a buyer-supplier relationship with higher levels of collaborative activity and cooperative attitudes successfully reduced costs while increasing sales and profits.

\subsubsection{Operational and Innovation Performance}

Revilla and Knoppen [85] found that collaborative relationships with buyers and suppliers improved operational efficiency and facilitated the development of new market strategies in a survey of 133 Spanish manufacturing firms. [86] investigated the effect of collaborative relationship on flexibility and innovativeness amongst South African steel and engineering firms. Their findings indicated that collaborative relationship aided in the relatively quick modification of the system and process, enhanced the material handling system, reduced the lead times and improved on-time delivery, as well as resulted in an easy-to-change product design.

\subsubsection{Financial and Operational Performance}

Bag et al. [86] demonstrated how a collaborative relationship between suppliers and buyers involved in the purchase of industrial analyser systems reduced the ratios of actual- 
to-estimated project costs, reduced delays in deliverable shipments and boosted the gross profit margin. Jones et al. [89] surveyed 138 senior purchasing managers of SMEs to examine suppliers' collaborative relationship. According to the results of the structural equation modelling, collaborative relationship has a significant positive effect on the overall competitive strength, market share growth, growth in return on assets, cost of purchased items, on-time delivery and productivity.

\subsubsection{Environmental and Social Performance}

León-Bravo et al. [102] conducted a multi-case study of four food supply chain stages, namely, breeding, processing, distribution and retail, and discovered that collaborative relationship has a positive effect on each stage. The collaborative relationship in the breeding stage benefits soil conservation and animal welfare significantly, whereas it reduced packaging, optimised transportation and improved spreading know-how, advance payments and economic development support in the processing stage. During the distribution stage, collaborative relationships improved transport management, logistic assets sharing and reduced pollutant emissions. A collaborative relationship in the retail stage improved social sustainability, reduced travel distances and reduced packaging. Dora [122] discovered that the farmers' collaborative supply chain relationship successfully reduced food waste while also sharing waste management practices knowledge.

Yazici [95] conducted a survey of 57 managers from a US service organisation to investigate the collaborative relationship between buyers and suppliers. According to the results of partial least square structural equation modelling, the collaborative relationship increased sales, market share and revenue. A survey of 350 Chinese manufacturing firms by $\mathrm{Li}$ et al. [78] investigated the effect of a collaborative relationship on financial performance. The findings indicated that collaborative relationships increased sales, profits, market share, return on investment and return on sales.

\subsubsection{Operational Performance}

The findings of multiple linear regression analysis demonstrated that greater collaboration with demand chain partners contributes to improved operational performance, such as shorter delivery lead times; on-time customer deliveries; lower inventory turnover rates; and lower rejected, rework and scrap levels [81]. Lavastre et al. [82] surveyed 164 managers from 41 companies from different French manufacturing industries and found that collaborative relationships between industrial and supply partners succeeded in improving operational efficiency. Amadi-Echendu and Krüger [98] investigated collaborative relationship between various players in the South African conveyancing supply chain process and discovered that it improved overall operational efficiency. Gu et al. [87] investigated the effect of collaborative relationship on operational performance by surveying 219 managers from various supply chain functional areas. The collaborative relationship with buyers and suppliers successfully shortened the delivery cycle time and lead time, reduced the number of damaged or defective products shipped, improved on-time delivery performance and reduced returns processing cost. Pongsathornwiwat et al. [100] surveyed 84 hotels in Bangkok, Thailand, to assess the effect of collaborative relationship on operational performance. The results of the ordinary least squares regression indicated that a collaborative relationship improved the operational efficiency and accelerated service delivery.

\subsection{Sustainability Issues in the B2B Supply Chain Relationship}

A review of six papers identified several sustainability issues in B2B supply chain relationships. Sheu [83] discussed the brander-retailer bidirectional green supply chains of fashionable consumer electronics products. His research findings reveal that the thirdparty power intervention-oriented social and political power enhance the collaborative relationship of dyadic members, leading to improved green supply chain performance in the aspects of economic, operational and environmental performance. Another researcher addressed the importance of collaboration in the food supply chain for long-term 
sustainability [102]. Despite the many previous studies on the impact of implementing sustainability practices in the food industry, studies identifying the sustainability practices used in collaboration across different supply chain stages (e.g., breeding, processing, distribution and retail) remain scarce. Ding et al. [124] discussed the coopetition relationship between a manufacturer and a collector in China's reverse supply chain collection of mobile phone waste. Their research is critical, particularly in China, because it is the world's largest producer and seller of mobile phones. As such, mobile phone waste in China is massive, contributing to an environmental problem. Zhu et al. [105] discussed the concept of contractors' opportunistic behaviour in mega-project green supply chains. There has yet to be a study on cross cooperation in the construction industry's green supply chain, as previous studies have primarily focused on the selection approach of green suppliers and technological realisation. Other researchers emphasised the significance of flexibility and innovation in configuring the sustainability in supply network [86]. Their findings reveal that organisation culture plays an important role in shaping the workforce behaviour and is responsible for improving green supplier developments and building strong relations with suppliers, resulting in increased innovativeness and flexibility. Dora [122] explored on how farmers manage stakeholder relationship in the supply chain to reduce food waste within the circular economy framework. Food waste management is critical. Investigating how collaborating with supply chain stakeholders can support its management within the framework of the circular economy is necessary, particularly from the perspective of farmers.

\section{Discussion and Future Research}

\subsection{Discussion}

This study attempted to systematically review the existing literature on supply chain relationships between B2B partners. A systematic search of the existing literature from two main academic databases, WoS and Scopus, identified 67 relevant papers that were mined for insights. The findings emphasised several insights. The current study recognised four research questions.

In response to the first research question, analyses of all 67 papers revealed that the B2B supply chain relationship approaches could be divided into three broad categories, namely, trust-based, power-based and coopetition approaches. Particularly, the trust-based approach is the most widely used in B2B relationships. Trust is primarily described as a belief that a promise made by a business partner is believable and that the partner acts in the manner that the trusting party expects [1]. It is faith in a business partner's dependability, honesty and integrity that ensures the accomplishment of a particular task [129]. Trust is the main element that contributes to the long-term orientation of supply relationships [130], in addition to the foundation and soul of supply chain management [131].

In response to the second research question, the majority of B2B partners used collaborative relationships, with only a few using coordination, adversarial, competitive and coopetitive relationships. Collaborative relationships involve interdependence between two parties to achieve common goals [112], and it is a long-term relationship with sharing of benefits and risks amongst parties [36]. Furthermore, the collaborative relationships between organisations are expected to contribute more to buyer performance than transactional relationships via the supplier's ability to provide the outsourced service [112].

In response to the third research question, almost all of the countries studied examined the trust-based approaches in their B2B relationships, such as collaborative, cooperative and coordination relationships. The majority of papers on B2B supply chain relationship approaches have been published in China, the US and the UK. Particularly, Chinese researchers are interested in trust-based approaches, trust-based and power-based approaches and coopetition approaches; in turn, researchers from the US and the UK mainly focus on trust-based approaches and trust- and power-based approaches.

In response to the fourth research question, the findings revealed that collaborative relationships have positive effects on financial, innovation, operational, environ- 
mental, social and economic performance. Collaborative relationships improve financial performance by increased sales, profitability, revenue, return on assets, relative market share, return on investment and return on sales $[18,75,83,89,95,112,117,119,121]$. Operational performance improves as a result of collaborative relationships in terms of reduction in investment, operational cost, order cycle times, safety stock levels, cycle time and total life cycle and improvement in inventory levels, fill rate and delivery timeliness $[74,75,80,82,83,85,86,98,100,110,112,117,119,121]$. Collaborative relationships improve innovation performance by increasing the anticipatory response level, radical and incremental innovations, enhancing the process and creation of new products and facilitating the development of new market strategies $[74,80,85,86,121]$. For the environmental performance, collaborative relationships provide efficient used-product collection; help obtain ISO 14000 certificates; achieve the goals of electronic waste management; and reduce pollution emissions, reduce food waste, travel distances and packaging [83,102,122]. In terms of social performance, collaborative relationship successfully decreases the workforce, managed to share waste management practices knowledge and improves the image of green brands, environmental concerns and exporter satisfaction [83,110,112,122]. Lastly, a collaborative relationship affects economic performance in terms of reduced costs and exporters' cost savings, as well as increased productivity $[18,74,75,80,110,112]$.

In response to the fifth research question, this study identified several sustainability issues in B2B supply chain relationships that researchers previously discussed in the selected papers. Previous researchers were interested in green supply chain [83], collaboration for sustainability in the food supply chain [102], coopetitive relationship in reverse supply chain collection of waste mobile phone [124], green supply chains [105], sustainability in supply network [86] and the significant importance of collaborative relationship in food waste management [122]. These findings highlight the significance of B2B supply chain relationships in achieving an organisation's sustainability performance. For instance, the authors in [83] demonstrated that collaborative relationship successfully improves the environmental, economic and social performance of the green supply chain. In addition, sustainable or long-term competitiveness in supply chains offer benefits that can be realised via collaboration of two or more actors [101]. Furthermore, the coordination relationship between various supply chain stages is critical for the success of global business optimisation [27]. The coordination relationship is essential for assisting supply chain members and increasing sustainable chain profitability.

\subsection{Future Research}

The findings could lead to several recommendations for future research. First, the research on the coopetition approach between B2B partners is still at the early stage and limited with only two studies that have been conducted recently. The two studies were conducted in China and Spain. As a result, more research should be conducted in this area, because coopetitive relationship is still relatively new in supply chain management, even though it is the most advantageous relationship [50]. Second, future studies on B2B supply chain relationships should be conducted in Southeast Asia, as only one study was performed in Southeast Asia, which was conducted in Thailand, such that results or findings can be generalised globally. Third, more research should be conducted on SMEs, because only 3 out of 67 studies have been conducted on SMEs $[50,90,103]$. SMEs represent the largest number of companies worldwide and play an important role in the generation of jobs and global economic development. Therefore, B2B relationships of SMEs should be thoroughly studied, because the competence of SMEs is limited by the size and number of resources available. B2B relationships should offer a means to extend their resource base to SMEs. Lastly, although electronic keyword searches are widely acknowledged as the best and most common method for conducting systematic analysis, supplementary search techniques are recommended for researchers instead of electronic keywords searches to find existing research papers [132,133]. Recommendations for the supplementary search techniques include (i) reference checking, which is the process of looking for additional 
papers in the reference list at the end of a selected paper [132]; (ii) citation searching, which is the process of identifying potential or additional papers by utilising the citation network that surrounds an original paper [134]; and (iii) consulting an expert if the researchers are unsure about the literature [135].

\section{Conclusions}

This study utilised a systematic review method to explore the supply chain relationship approaches between B2B partners and their effects on supply chain performance as well as the sustainability issues. Extant research shows that the trust-based approach is the most common in B2B relations. Particularly, most of the B2B partners have a collaborative relationship, and only a few of them adopt coordination, adversarial, competitive and coopetitive relationships. In addition, almost all of the countries studied employed trustbased approaches in their B2B relationship, with the majority of papers published in China, the US and the UK. The findings showed the positive effects of collaborative relationships on supply chain performance, including financial, innovation, operational, environmental, social and economic performances. The findings also revealed the importance of supply chain relationships between B2B partners in achieving organisation sustainability. Investigating the supply chain relationships of B2B partners systematically is essential from theoretical and practical perspectives as it provides a more general overview of the business supply chain relationships. However, this study has limitations that should be addressed in future studies. Firstly, research on the coopetition approach between B2B partners is limited yet it is found to be the most beneficial. Future studies should focus more on this type of relationship. Secondly, only one study was conducted in Southeast Asia; more studies should be conducted in Southeast Asia in the future as the relationship between B2B partners in Southeast Asia may be differ to that in the rest of Asia or European countries. Furthermore, more research on SMEs' B2B relationship should be conducted because SMEs account for the vast majority of businesses globally. This study found that less than five percent of the selected studies focus on SMEs' B2B relationships. Addressing these gaps enhances the understanding of the roles of supply chain relationship management towards achieving economic, environmental and social sustainability. This understanding is crucial as globalisation creates numerous players along a supply chain, which makes it a more complex and challenging task to excel at.

Author Contributions: Conceptualization, N.S.; methodology, F.J.; validation, N.S.; formal analysis, F.J.; investigation, F.J. and N.S.; resources, F.J.; data curation, F.J. and N.S.; writing-original draft preparation, F.J.; writing-review and editing, F.J. and N.S.; visualization, F.J.; supervision, N.S.; funding acquisition, N.S. All authors have read and agreed to the published version of the manuscript.

Funding: This research was funded by UKM-Research Incentive Scheme Grant (GGP-2019-006).

Institutional Review Board Statement: Not applicable.

Informed Consent Statement: Not applicable.

Data Availability Statement: Data sharing is not applicable to this article.

Conflicts of Interest: The authors declare no conflict of interest.

\section{References}

1. Ryciuk, U.; Nazarko, J. Model of trust-based cooperative relationships in a supply chain. J. Bus. Econ. Manag. 2020, 21, 1225-1247. [CrossRef]

2. Alonso, A.D. Importance of Relationships among Small Accommodation Operations around the City of Perth. Tour. Hosp. Res. 2010, 10, 14-24. [CrossRef]

3. Beier, M.; Hauser, C.; Hogenacker, J. Domestic business-to-business relationships and the internationalisation of SMEs: Evidence from Switzerland. Int. J. Entrep. Ventur. 2016, 8, 84-101. [CrossRef]

4. Thomas, R.W.; Esper, T.L.; Stank, T.P. Coping with time pressure in interfirm supply chain relationships. Ind. Mark. Manag. 2011, 40, 414-423. [CrossRef] 
5. Hoyt, J.; Huq, F. From arms-length to collaborative relationships in the supply chain. Int. J. Phys. Distrib. Logist. Manag. 2000, 30, 750-764. [CrossRef]

6. Marcinkowski, J.M.; Kutzner, I.M.; Bożydaj-Jankowska, I. Dysfunctions in B2B relations with a supplier in the supply chain. Pr. Nauk. Uniw. Ekon. We Wroclawiu 2019, 63, 256-270. [CrossRef]

7. Marcinkowski, J.M.; Kutzner, I.M. Framework for Modeling the Measurement of Dysfunctions in B2B Relations in the Supply Chain; Carpathian Logistics Congress: Zakopane, Poland, 2019.

8. Jelinek, R. Loyalty or lethargy? Keeping sellers committed, not entrenched. Bus. Horiz. 2021, 64, 61-71. [CrossRef]

9. Anderson, E.; Jap, S.D. The dark side of close relationships. MITSloan Manag. Rev. 2005, 46, 75-82.

10. Porterfield, T.E.; MaCdonald, J.R.; Griffis, S.E. An exploration of the relational effects of supply chain disruptions. Transp. J. 2012, 51, 399-427. [CrossRef]

11. Dirks, K.T.; Lewicki, R.J.; Zaheer, A. Reparing Relationships Within and Between Organizations: Building A Conceptual Foundation. Acad. Manag. Rev. 2009, 34, 68-84. [CrossRef]

12. Wang, Q.C.; Craighead, W.; Li, J.J. Justice served: Mitigating damaged trust stemming from supply chain disruptions. J. Oper. Manag. 2014, 32, 374-386. [CrossRef]

13. Macdonald, J.R.; Corsi, T.M. Supply Chain Disruption Management: Severe Events, Recovery and Performance. J. Bus. Logist. 2013, 34, 270-288. [CrossRef]

14. Katsaliaki, K.; Galetsi, P.; Kumar, S. Supply chain discruptions and resilience: A major review and future research agenda. Ann. Oper. Res. 2021, 1-38.

15. Ritter, L.; Barrett, J.M.; Willson, R.A. Securing Global Transportation Networks: A Total Security Management Approach; McGraw-Hill: New York, NY, USA, 2007.

16. Meyer, A.; Walter, W.; Seuring, S. The Impact of the Coronavirus Pandemic on Supply Chains and Their Sustainability: A Text Mining Approach. Front. Sustain. 2021, 2, 1-23. [CrossRef]

17. Young, L.C.; Wilkinson, I.F. The role of trust and cooperation in marketing channels: A preliminary study. Eur. J. Mark. 1989, 23, 109-122. [CrossRef]

18. Duffy, R.; Fearne, A. The Impact of Supply Chain Partnerships on Supplier Performance. Int. J. Logist. Manag. 2004, 15, 57-72. [CrossRef]

19. Kähkönen, A. The influence of power position on the depth of collaboration. Supply Chain Manag. 2014, 19, 17-30. [CrossRef]

20. Sanders, N.R. Supply Chain Management: A Global Perspective; John Wiley \& Sons, Inc.: Hoboken, NJ, USA, 2011.

21. Vargo, S.L.; Lusch, R.F. Evolving to a New Dominant Logic for Marketing. J. Mark. 2004, 68, 1-17. [CrossRef]

22. Ulaga, W.; Eggert, A. Relationship value and relationship quality. Eur. J. Mark. 2006, 40, 311-327. [CrossRef]

23. Barry, J.; Terry, T.S. Empirical study of relationship value in industrial services. J. Bus. Ind. Mark. 2008, 23, 228-241. [CrossRef]

24. Leonidou, L.C. Industrial manufacturer-customer relationships: The discriminating role of the buying situation. Ind. Mark. Manag. 2004, 33, 731-742. [CrossRef]

25. Geyskens, I.; Steenkamp, J.-B.; Kumar, N. A meta-analysis of satisfaction in marketing channel relationships. J. Mark. Res. 1999, 36, 223-238. [CrossRef]

26. Kac, S.M.; Gorenak, I.; Potocan, V. The influence of trust on collaborative relationships in supply chains. Ekon. Manag. 2016, 19, 120-131.

27. Lemma, H.R.; Singh, R.; Kaur, N. Determinants of supply chain coordination of milk and dairy industries in Ethiopia: A case of Addis Ababa and its surroundings. Springerplus 2015, 4, 498-510. [CrossRef] [PubMed]

28. Tolmay, A.S.; Badenhorst-Weiss, J.A. Supply chain relationships between first and second tier suppliers in South African automotive supply chains: A focus on trust. J. Transp. Supply Chain Manag. 2015, 9, 1-8. [CrossRef]

29. Towers, N.; Burnes, B. A composite framework of supply chain management and enterprise planning for small and medium-sized manufacturing enterprises. Supply Chain Manag. An Int. J. 2008, 13, 349-355. [CrossRef]

30. Aitken, A.; Paton, R.A. The 'T-Shaped Buyer': A transactional perspective on supply chain relationships. J. Purch. Supply Manag. 2017, 23, 280-289. [CrossRef]

31. Nair, A.; Narasimhan, R.; Bendoly, E. Coopetitive Buyer-Supplier Relationship: An Investigation of Bargaining Power, Relational Context, and Investment Strategies. Decis. Sci. 2011, 42, 93-126. [CrossRef]

32. Shahzad, K.; Takala, J.; Ali, T.; Sillanpää, I. Managing for Success: The Role of Transactional and Relational Mechanisms in Buyer-Supplier Relationships. Management 2015, 10, 35-59.

33. Ralston, P.M.; Richey, R.G.; Grawe, S.J. The past and future of supply chain collaboration: A literature synthesis and call for research. Int. J. Logist. Manag. 2017, 28, 508-530. [CrossRef]

34. Wright, G.H.; Taylor, A. Strategic partnerships and relationship marketing in healthcare. Public Manag. Rev. 2005, 7, 203-224. [CrossRef]

35. Shin, N.; Park, S.H.; Park, S. Partnership-based supply chain collaboration: Impact on commitment, innovation, and firm performance. Sustainability 2019, 11, 449. [CrossRef]

36. Whipple, J.M.; Lynch, D.F.; Nyaga, G.N. A buyer's perspective on collaborative versus transactional relationships. Ind. Mark. Manag. 2010, 39, 507-518. [CrossRef]

37. Daugherty, P.J.; Richey, R.G.; Roath, A.S.; Min, S.; Chen, H.; Arndt, A.D.; Genchev, S.E. Is collaboration paying off for firms? Bus. Horiz. 2006, 49, 61-70. [CrossRef] 
38. May, P.J.; Winter, S.C. Collaborative service arrangements. Public Manag. Rev. 2007, 9, 479-502. [CrossRef]

39. Mahmud, P.; Paul, S.K.; Azeem, A.; Chowdhury, P. Evaluating supply chain collaboration barriers in smalland medium-sized enterprises. Sustainability 2021, 13, 7449. [CrossRef]

40. Hazen, B.T.; Byrd, T.A. Toward creating competitive advantage with logistics information technology. Int. J. Phys. Distrib. Logist. Manag. 2012, 42, 8-35. [CrossRef]

41. Nagle, T.; Finnegan, P.; Hayes, J. From tough negotiation to complex integration: Implications of adversarial and collaborative relationships on electronic procurement systems. Inf. Resour. Manag. J. 2009, 22, 64-84. [CrossRef]

42. Meng, X. Change in uk construction: Moving toward supply chain collaboration. J. Civ. Eng. Manag. 2013, 19, 422-432. [CrossRef]

43. Min, S.; Roath, A.S.; Daugherty, P.J.; Genchev, S.E.; Chen, H.; Arndt, A.D.; Richey, G. Supply chain collaboration: What's happening? Int. J. Logist. Manag. 2005, 16, 237-256. [CrossRef]

44. Cao, M.; Zhang, Q. Supply chain collaboration: Impact on collaborative advantage and firm performance. J. Oper. Manag. 2011, 29, 163-180. [CrossRef]

45. Nyaga, G.N.; Whipple, J.M.; Lynch, D.F. Examining supply chain relationships: Do buyer and supplier perspectives on collaborative relationships differ? J. Oper. Manag. 2010, 28, 101-114. [CrossRef]

46. Grant, D.B. The Transaction-Relationship Dichotomy in Logistics and Supply Chain Management. Supply Chain Forum Int. J. 2005, 6, 38-48. [CrossRef]

47. Vanichchinchai, A. The effect of lean manufacturing on a supply chain relationship and performance. Sustainability 2019, 11, 5751. [CrossRef]

48. Oh, A. Development of a smart supply-chain management solution based on logistics standards utilizing artificial intelligence and the internet of things. J. Inf. Commun. Converg. Eng. 2019, 17, 198-204.

49. Galdeano-Gómez, E.; Pérez-Mesa, J.C.; Giagnocavo, C.L. Food exporters and co-opetition relationships: An analysis on the vegetable supply chain. Electron. Libr. 2015, 117, 1596-1609. [CrossRef]

50. Raza-Ullah, T. When does (not) a coopetitive relationship matter to performance? An empirical investigation of the role of multidimensional trust and distrust. Ind. Mark. Manag. 2021, 96, 86-99. [CrossRef]

51. Gnyawali, D.R.; Ryan Charleton, T. Nuances in the Interplay of Competition and Cooperation: Towards a Theory of Coopetition. J. Manag. 2018, 44, 2511-2534. [CrossRef]

52. Arshinder, K.; Kanda, A.; Deshmukh, S.G. A Review on Supply Chain Coordination Mechanisms, Managing Uncertainty and Research Directions. In Supply Chain Coordination under Uncertainty. International Handbooks on Information Systems; Choi, T.M., Cheng, T., Eds.; Springer: Berlin/Heidelberg, Germany, 2011; pp. 39-82.

53. Chen, L.; Zhao, X.; Tang, O.; Price, L.; Zhang, S.; Zhu, W. Supply chain collaboration for sustainability: A literature review and future research agenda. Int. J. Prod. Econ. 2017, 194, 73-87. [CrossRef]

54. Singh, H.; Garg, R.K.; Sachdeva, A. Supply chain collaboration: A state-of-the-art literature review. Uncertain Supply Chain Manag. 2018, 6, 149-180. [CrossRef]

55. Ho, D.; Kumar, A.; Shiwakoti, N. A Literature Review of Supply Chain Collaboration Mechanisms and Their Impact on Performance. EMJ Eng. Manag. J. 2019, 31, 47-68. [CrossRef]

56. Wankmüller, C.; Reiner, G. Coordination, cooperation and collaboration in relief supply chain management. J. Bus. Econ. 2019, 90, 239-276. [CrossRef]

57. Chen, Q.; Hall, D.M.; Adey, B.T.; Haas, C.T. Identifying enablers for coordination across construction supply chain processes: A systematic literature review. Eng. Constr. Archit. Manag. 2020, 28, 1083-1113. [CrossRef]

58. Qian, C.; Seuring, S.; Wagner, R. Reviewing interfirm relationship quality from a supply chain management perspective. Manag. Rev. Q. 2020, 71, 625-650. [CrossRef]

59. Aloui, A.; Hamani, N.; Derrouiche, R.; Delahoche, L. Systematic literature review on collaborative sustainable transportation: Overview, analysis and perspectives. Transp. Res. Interdiscip. Perspect. 2021, 9, 100291.

60. Hamidin, D.; Rofaida, R. Outsourcing Supply Chain: Systematic Literature Review on Innovation Driver Factors Towards Collaborative Network. J. Bisnis Dan Manaj. 2021, 22, 3-18. [CrossRef]

61. Daghar, A.; Alinaghian, L.; Turner, N. The role of collaborative interorganizational relationships in supply chain risks: A systematic review using a social capital perspective. Supply Chain Manag. Int. J. 2021, 26, 279-296. [CrossRef]

62. Higgins, J.P.T.; Altman, D.G.; Gotzsche, P.C.; Juni, P.; Moher, D.; Oxman, A.D.; Savovic, J.; Schulz, K.F.; Weeks, L.; Sterne, J.A.C.; et al. The Cochrane Collaboration's tool for assessing risk of bias in randomised trials. BMJ 2011, 343, 1-9. [CrossRef]

63. Nisrine, K.; Rhizlane, B. The exchange relationship between logistics partners and its impact on the performance of SCM A Systematic and PRISMA method. In Proceedings of the 2019 International Colloquium on Logistics and Supply Chain Management (LOGISTIQUA), Montreuil, Paris, France, 12-14 June 2019.

64. Sierra-Correa, P.C.; Cantera Kintz, J.R. Ecosystem-based adaptation for improving coastal planning for sea-level rise: A systematic review for mangrove coasts. Mar. Policy 2015, 51, 385-393. [CrossRef]

65. Web of Science: Clarivate. Available online: https://clarivate.com/webofsciencegroup/solutions/web-of-science/ (accessed on 30 August 2021).

66. Li, K.; Rollins, J.; Yan, E. Web of Science use in published research and review papers 1997-2017: A selective, dynamic, crossdomain, content-based analysis. Scientometrics 2018, 115, 1-20. [CrossRef] 
67. What Is Scopus Preview? Scopus. Available online: https://service.elsevier.com/app/answers/detail/a_id/15534/supporthub/ scopus/\#tips (accessed on 30 August 2021).

68. González-albo, B.; Bordons, M. Articles vs. proceedings papers: Do they differ in research relevance and impact? A case study in the Library and Information Science field. J. Informetr. 2011, 5, 369-381. [CrossRef]

69. Jackson, D.; Davison, I.; Adams, R.; Edordu, A.; Picton, A. A systematic review of supervisory relationships in general practitioner training. Med. Educ. Rev. 2019, 53, 874-885. [CrossRef] [PubMed]

70. Mallett, R.; Hagen-Zanker, J.; Slater, R.; Duvendack, M. The benefits and challenges of using systematic reviews in international development research. J. Dev. Eff. 2012, 4, 445-455. [CrossRef]

71. Xiao, Y.; Watson, M. Guidance on Conducting a Systematic Literature Review. J. Plan. Educ. Res. 2017, 39, 93-112. [CrossRef]

72. Dixon-Woods, M.; Agarwal, S.; Jones, D.; Young, B.; Sutton, A. Synthesising qualitative and quantitative evidence: A review of possible methods. J. Health Serv. Res. Policy 2005, 10, 45-53. [CrossRef] [PubMed]

73. Liberati, A.; Altman, D.G.; Tetzlaff, J.; Mulrow, C.; Gotzsche, P.C.; Ioannidis, J.P.A.; Clarke, M.; Devereaux, P.J.; Kleijnen, J.; Moher, D. The PRISMA statement for reporting systematic reviews and meta-analyses of studies that evaluate health care interventions: Explanation and elaboration. PLoS Med. 2009, 6, e1000100-e1000128. [CrossRef] [PubMed]

74. Soosay, C.A.; Hyland, P.W.; Ferrer, M. Supply chain collaboration: Capabilities for continuous innovation. Supply Chain Manag. Int. J. 2008, 13, 160-169. [CrossRef]

75. Whipple, J.M.; Russell, D. Building supply chain collaboration: A typology of collaborative approaches. Int. J. Logist. Manag. 2007, 18, 174-196. [CrossRef]

76. Akintoye, A.; Main, J. Collaborative relationships in construction: The UK contractors' perception. Eng. Constr. Archit. Manag. 2007, 14, 597-617. [CrossRef]

77. Tomlinson, P.R.; Fai, F.M. The nature of SME co-operation and innovation: A multi-scalar and multi-dimensional analysis. Int. J. Prod. Econ. 2013, 141, 316-326. [CrossRef]

78. Li, G.; Fan, H.; Lee, P.K.C.; Cheng, T.C.E. Joint supply chain risk management: An agency and collaboration perspective. Int. J. Prod. Econ. 2015, 164, 83-94. [CrossRef]

79. Humphreys, P.K.; Shiu, W.K.; Chan, F.T.S. Collaborative relationships in Hong Kong manufacturing firms. Supply Chain Manag. Int. J. 2001, 6, 152-162. [CrossRef]

80. Jean, R.B.; Sinkovics, R.R. Relationship learning and performance enhancement via advanced information technology: The case of Taiwanese dragon electronics firms. Int. Mark. Rev. 2010, 27, 200-222. [CrossRef]

81. Iyer, K.N.S. Demand chain collaboration and operational performance: Role of IT analytic capability and environmental uncertainty. J. Bus. Ind. Mark. 2011, 26, 81-91. [CrossRef]

82. Lavastre, O.; Gunasekaran, A.; Spalanzani, A. Effect of firm characteristics, supplier relationships and techniques used on Supply Chain Risk Management (SCRM): An empirical investigation on French industrial firms. Int. J. Prod. Res. 2014, 52, 3381-3403. [CrossRef]

83. Sheu, J. Green supply chain collaboration for fashionable consumer electronics products under third-party power intervention-A resource dependence perspective. Sustainability 2014, 6, 2832-2875. [CrossRef]

84. Whipple, J.M.; Wiedmer, R.; Boyer, K.K. A Dyadic Investigation of Collaborative Competence, Social Capital, and Performance in Buyer-Supplier Relationships. J. Supply Chain Manag. 2015, 51, 3-21. [CrossRef]

85. Revilla, E.; Knoppen, D. Building knowledge integration in buyer-supplier relationships: The critical role of strategic supply management and trust. Int. J. Oper. Prod. Manag. 2015, 35, 1408-1436. [CrossRef]

86. Bag, S.; Gupta, S.; Telukdarie, A. Importance of innovation and flexibility in configuring supply network sustainability. Benchmarking Int. J. 2018, 25, 3951-3985. [CrossRef]

87. Gu, V.C.; Cao, R.Q.; Black, K.; Zeng, H. Managing collaborative relationships in third party logistics: An empirical study. Int. J. Inf. Syst. Supply Chain Manag. 2017, 10, 42-65. [CrossRef]

88. Patrucco, A.S.; Luzzini, D.; Moretto, A.; Ronchi, S. Attraction in buyer-supplier relationships: Improving supply network performance through purchasing recognition and proficient collaboration initiatives. Bus. Process Manag. J. 2019, 25, 347-367. [CrossRef]

89. Jones, S.L.; Fawcett, S.E.; Wallin, C.; Fawcett, A.M.; Brewer, B.L. Can small firms gain relational advantage? Exploring strategic choice and trustworthiness signals in supply chain relationships. Int. J. Prod. Res. 2014, 52, 5451-5466. [CrossRef]

90. Gandhi, S.K.; Sachdeva, A.; Gupta, A. Impact of service quality on satisfaction and loyalty at manufacturer-distributor dyad: Insights from Indian SMEs. J. Adv. Manag. Res. 2019, 16, 91-122. [CrossRef]

91. Chaston, I.; Mangles, T. Business networks: Assisting knowledge management and competence acquisition within UK manufacturing firms. J. Small Bus. Enterp. Dev. 2000, 7, 160-170. [CrossRef]

92. Si, W.; Ma, J. Corporation in a closed-loop supply chain based on remanufacturing. WSEAS Trans. Math. 2013, 12, 482-490.

93. Ming, H.; Shuyu, H. Revenue sharing contract of the green supply chain based on centralized decision making and the game model. Metall. Min. Ind. 2015, 7, 408-415.

94. Yeh, Y. Critical influence of relational governance on relationship value in strategic supply management. Eur. Bus. Rev. 2016, 28, 137-154. [CrossRef]

95. Yazici, H.J. Buyer perceptions on the buyer-supplier collaborative relationship and performance: A service example. Int. J. Serv. Oper. Manag. 2012, 12, 165-187. [CrossRef]

96. Lehtonen, T. Collaborative relationships in facility services. Leadersh. Organ. Dev. J. 2006, 27, 429-444. [CrossRef] 
97. Plane, C.V.; Green, A.N. Buyer-supplier collaboration: The aim of FM procurement? Facilities 2012, 30, 152-163. [CrossRef]

98. Amadi-Echendu, A.P.; Krüger, L.P. Supply chain integration in the South African conveyancing environment. J. Transp. Supply Chain Manag. 2016, 10, 1-13. [CrossRef]

99. Tong, P.; Umesh, U.N.; Johnson, J.L.; Lee, R.P. Collaborative Relationships-The Role of Information Technology. Int. J. Innov. Technol. Manag. 2016, 13, 1640006. [CrossRef]

100. Pongsathornwiwat, A.; Udomvitid, K.; Jeenanunta, C.; Huynh, V.N. Can collaborative relationship stimulate innovation capability and improve performance in the hospitality industry. Int. J. Innov. Learn. 2019, 26, 321-342. [CrossRef]

101. Kottila, M.; Rönni, P. Collaboration and trust in two organic food chains. Br. Food J. 2008, 110, 376-394. [CrossRef]

102. León-Bravo, V.; Caniato, F.; Caridi, M.; Johnsen, T. Collaboration for sustainability in the food supply chain: A multi-stage study in Italy. Sustainability 2017, 9, 1253. [CrossRef]

103. Ho, D.C.K.; Mo, D.Y.W.; Wong, E.Y.C.; Leung, S.M.K. Business intelligence for order fulfilment management in small and medium enterprises. Int. J. Internet Manuf. Serv. 2019, 6, 169-184. [CrossRef]

104. Yin, S.Y.; Tserng, H.P.; Toong, S.N.; Ngo, T.L. An improved approach to the subcontracting procurement process in a lean construction setting. J. Civ. Eng. Manag. 2014, 20, 389-403. [CrossRef]

105. Zhu, J.; Fang, M.; Shi, Q.; Wang, P.; Li, Q. Contractor cooperation mechanism and evolution of the green supply chain in mega projects. Sustainability 2018, 10, 4306. [CrossRef]

106. Shi, Q.; Zhu, J.; Li, Q. Cooperative Evolutionary Game and Applications in Construction Supplier Tendency. Complexity 2018. [CrossRef]

107. Song, H.; Zhu, F.; Klakegg, O.J.; Wang, P. Relationship between contractual flexibility and contractor's cooperative behavior: The mediating effect of justice perception. Int. J. Manag. Proj. Bus. 2018, 11, 382-405. [CrossRef]

108. Chen, H.; Tian, Y.; Ellinger, A.E.; Daugherty, P.J. Managing Logistics Outsourcing Relationships: An Empirical Investigation in China. J. Bus. Logist. 2010, 31, 279-299. [CrossRef]

109. Seo, Y.; Dinwoodie, J.; Roe, M. Measures of supply chain collaboration in container logistics. Marit. Econ. Logist. 2015, 17, 292-314. [CrossRef]

110. Park, Y.; Jeong, Y. An empirical analysis on the performance of the third-party logistics in the Korean exporter. J. Korea Trade 2016, 20, 97-114. [CrossRef]

111. Cha, K.; Kim, Y.S. Critical success factors for mutual collaboration with suppliers in IT outsourcing industry: A case study of a top IT outsourcing company in Korea. Enterp. Inf. Syst. 2018, 12, 76-95. [CrossRef]

112. Martins, A.L.; Duarte, H.; Costa, D. Buyer-supplier relationships in IT outsourcing: Consultants' perspective. Int. J. Logist. Manag. 2018, 29, 215-1236. [CrossRef]

113. Gupta, S.; Foroudi, P.; Yen, D. Investigating relationship types for creating brand value for resellers. Ind. Mark. Manag. 2018, 72, 37-47. [CrossRef]

114. Lockström, M.; Schadel, J.; Harrison, N.; Moser, R.; Malhotra, M.K. Antecedents to supplier integration in the automotive industry: A multiple-case study of foreign subsidiaries in China. J. Oper. Manag. 2010, 28, 240-256. [CrossRef]

115. Lettice, F.; Wyatt, C.; Evans, S. Buyer-supplier partnerships during product design and development in the global automotive sector: Who invests, in what and when? Int. J. Prod. Econ. 2010, 127, 309-319. [CrossRef]

116. Wu, I.; Chuang, C. Analyzing contextual antecedents for the stage-based diffusion of electronic supply chain management. Electron. Commer. Res. Appl. 2009, 8, 302-314. [CrossRef]

117. Cheng, L.V.; Carrillo, E.E. Assessing supplier performances under partnership in project-type procurement. Ind. Manag. Data Syst. 2012, 112, 290-312. [CrossRef]

118. Kumar, G.; Banerjee, R.N.; Meena, P.L.; Ganguly, K. Collaborative culture and relationship strength roles in collaborative relationships: A supply chain perspective. J. Bus. Ind. Mark. 2016, 31, 587-599. [CrossRef]

119. Ryu, I.; So, S.; Koo, C. The role of partnership in supply chain performance. Ind. Manag. Data Syst. 2009, 109, 496-514. [CrossRef]

120. Hausman, A.; Stock, J.R. Adoption and implementation of technological innovations within long-term relationships. J. Bus. Res. 2003, 56, 681-686. [CrossRef]

121. Verdecho, M.; Alfaro-Saiz, J.; Rodriguez-Rodriguez, R.; Ortiz-Bas, A. A multi-criteria approach for managing inter-enterprise collaborative relationships. Omega 2012, 40, 249-263. [CrossRef]

122. Dora, M. Collaboration in a circular economy: Learning from the farmers to reduce food waste. J. Enterp. Inf. Manag. 2019, 33, 769-789. [CrossRef]

123. Wood, G.; Dibben, P.; Meira, J. Knowledge transfer within strategic partnerships: The case of HRM in the Brazilian motor industry supply chain. Int. J. Hum. Resour. Manag. 2016, 27, 2398-2414. [CrossRef]

124. Ding, Y.; Ma, L.; Zhang, Y.; Feng, D. Analysis of evolution mechanism and optimal reward-penalty mechanism for collection strategies in reverse supply chains: The case of waste mobile phones in China. Sustainability 2018, 10, 4744. [CrossRef]

125. He, Q.; Gallear, D.; Ghobadian, A. Knowledge transfer: The facilitating attributes in supply-chain partnerships. Inf. Syst. Manag. 2011, 28, 57-70. [CrossRef]

126. Gnanlet, A.; Choi, H.P. Impact of non-homogenous distributor's preferred allocation on shortages in hospitals. Manag. Decis. 2014, 52, 624-641. [CrossRef]

127. Zhao, Y.; Li, D.; Pan, L. Cooperation or competition: An evolutionary game study between commercial banks and big data-based e-commerce financial institutions in China. Discret. Dyn. Nat. Soc. 2015, 2015, 890972. [CrossRef] 
128. Ayakwah, A.; Sepulveda, L.; Lyon, F. Competitive or cooperative relationships in clusters: A comparative study of two internationalising agro-processing clusters in Ghana. Crit. Perspect. Int. Bus. 2018, 14, 230-251. [CrossRef]

129. Sahay, B.S. Understanding trust in supply chain relationships. Ind. Manag. Data Syst. 2003, 103, 553-563. [CrossRef]

130. Redondo, Y.P.; Cambra Fierro, J.J. Educational level as moderating element of long-term orientation of supply relationships. J. Mark. Manag. 2008, 24, 383-408. [CrossRef]

131. Zhou, G.; Fei, Y.; Hu, J. The Analysis of Vertical Transaction Behavior and Performance Based on Automobile Brand Trust in Supply Chain. Discret. Dyn. Nat. Soc. 2016, 2016, 4793851. [CrossRef]

132. Horsley, T.; Dingwall, O.; Tetzlaff, J.M.; Sampson, M. Checking reference lists to find additional studies for systematic reviews. Cochrance Database Syst. Rev. 2011. [CrossRef]

133. Tsafnat, G.; Glasziou, P.; Choong, M.K.; Dunn, A.; Galgani, F.; Coiera, E. Systematic review automation technologies. Syst. Rev. 2014, 3, 74. [CrossRef]

134. Briscoe, S.; Bethel, A.; Rogers, M. Conduct and reporting of citation searching in Cochrane systematic reviews: A cross-sectional study. Res. Synth. Methods 2020,11, 169-180. [CrossRef]

135. Gøtzsche, P.C.; Ioannidis, J.P.A. Content area experts as authors: Helpful or harmful for systematic reviews and meta-analyses? Br. Med. J. 2012, 345, e7031. [CrossRef] 